\title{
\#EdTechHub
}

Realising the potential of technology in education

\section{EdTech in Sierra Leone: A Rapid Scan}

Joel Mullan and Abeba Taddese

EdTech Hub, https://edtechhub.org

Country Scan

2020-06-30

DOI: 10.5281/zenodo.3903213

For enquiries please email helpdesk@edtechhub.org

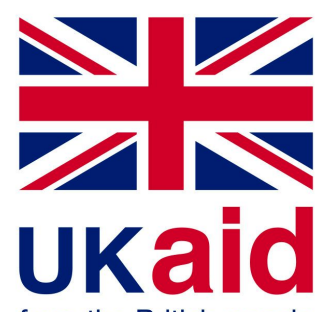




\section{About this document}

Recommended citation.

Licence.

Creative

Commons

Acknow-

ledgement

Identifiers.

Internal use.

$\mathrm{g} / \mathrm{d} / 15 \mathrm{H} \times \mathrm{p} 3 \mathrm{WIL} \times \mathrm{F}$
$\underline{\text { eecfbcf\&pli=1\# }}$

Reviewed by

James Bradley, Academics Manager, Rising Academies; Preeti Dhillon, Senior Researcher, Jigsaw Consult; Joel Mitchell, EdTech Hub

Mullan, J., and Taddese, A. (2020). EdTech in Sierra Leone: A Rapid Scan. (EdTech Hub Country Scan). DOI: 10.5281/zenodo.3903213. Available from https://docs.edtechhub.org/lib/C5MWWQI2 Available under Creative Commons Attribution 4.0 International, https://creativecommons.org/licenses/by/4.0/.

Creative Commons Attribution 4.0 International

https://creativecommons.org/licenses/by/4.0/.

You - dear readers - are free to share (copy and redistribute the material in any medium or format) and adapt (remix, transform and build upon the material) for any purpose, even commercially. You must give appropriate credit, provide a link to the license and indicate if changes were made. You may do so in any reasonable manner, but not in any way that suggests the licensor endorses you or your use.

N/A

\section{5:C5MWWQI; 10.5281/zenodo.3903213}

Notes.

The EdTech Hub is supported by UK aid from the UK government. The views expressed are the views of the authors and do not necessarily reflect views of our donors. 


\section{About this scan}

EdTech Hub country scans explore factors that enable and hinder the use of technology in education. This includes policies, government leadership, private-sector partnerships and digital infrastructure for education. The scans are intended to be comprehensive but are by no means exhaustive; nonetheless, we hope they will serve as a useful starting point for more in-depth discussions about opportunities and barriers in EdTech in specific countries and in this case, in Sierra Leone.

This report was originally written in June 2020. It is based primarily on desk research, with quality assurance provided by a country expert. Given how rapidly the educational technology landscape is evolving, the Hub plans to provide periodic updates. Table 1 provides a summary of the situation regarding EdTech in Sierra Leone.

\section{Table 1. EdTech in Sierra Leone}

\begin{tabular}{|c|c|}
\hline Policies & $\begin{array}{l}\text { - National Innovation and Digital Strategy, 2019-202911 } \\
\text { - No ICT for Education Policy currently exists }\end{array}$ \\
\hline Infrastructure & $\begin{array}{l}\text { - Upper secondary schools are better equipped with technologies than } \\
\text { primary schools, though overall absolute levels are low } \\
\text { - } 5.6 \% \text { of primary schools have electricity, compared to } 33.7 \% \text { of senior } \\
\text { secondary schools } \\
\text { - } 0.6 \% \text { of primary schools have access to the internet compared to } 7.8 \% \\
\text { of upper secondary schools } \\
\text { - At the household level, radios and mobile phones are the most } \\
\text { prevalent technologies. In urban areas, } 93.5 \% \text { of households have a } \\
\text { mobile phone compared to } 53.4 \% \text { in rural areas }\end{array}$ \\
\hline $\begin{array}{l}\text { Partners and } \\
\text { initiatives }\end{array}$ & $\begin{array}{l}\text { - Government- and development-partner-supported EdTech initiatives } \\
\text { have focused on improving education data, technology-enabled } \\
\text { teacher education and radio education as a response to school } \\
\text { closures during the Ebola epidemic and Covid-19 pandemic. Key } \\
\text { international partners have included the World Bank, DFID and } \\
\text { UNICEF. } \\
\text { - The Directorate of Science, Technology and Innovation collaborates } \\
\text { closely with the Education Ministry to support data-driven decision } \\
\text { making and to help catalyse innovation. } \\
\text { - The government has invested US\$1.5m in an outcome-based } \\
\text { Educational Innovation Challenge Fund, which is expected to focus on } \\
\text { EdTech interventions. }\end{array}$ \\
\hline
\end{tabular}

${ }^{1}$ Directorate of Science, Technology \& Innovation (2019a), available at https://www.dsti.gov.sl/wp-content/uploads/2019/11/Sierra-Leone-National-Innovation-and-Digital-S trategy.pdf 


\section{COVID-19}

- All schools closed on March 31, 2020, with an emergency radio education programme launched the following week

- In May 2020, the Government of Sierra Leone launched the COVID-19 Education Emergency Response Plan²

\section{Country overview}

Sierra Leone is a small country in West Africa. In 2018, it had a population of 7.65 million, which is increasing at a rate of $2.1 \%$ per year (UNESCO, 2020). Forty-one per cent of the population is below the age of 15 (Ibid.). The country is organised into four regional provinces. There are 13 district councils overseen by provincial authorities and six municipal councils overseen directly by the central government. At a local level, the country is organised into 149 chiefdoms. English is the official language, Krio is the lingua franca and significant minorities of the population speak Temne (37\%) and Mende (31\%).

Over the last 30 years, human and economic development in Sierra Leone has been constrained by conflict, disease and exposure to shifts in the price of export commodities. Between 1991 and 2002, the country was embroiled in a civil war, which left over 50,000 dead. Between 2014 and 2016, Sierra Leone was seriously affected by the West Africa Ebola epidemic, which killed more than 3,880 people. The outbreak saw all schools closed during the 2014 / 15 academic year and the country's economy contracted by more than $20 \%$.

In 2018, Sierra Leone had a Human Development Index (HDI) of 0.438, placing it in the low human development category and positioning it at 182 out of 189 countries and territories. Average life expectancy is 58 years, and $52 \%$ of the population live below the poverty line (Ibid.). Fifty-eight per cent of the population live in rural areas, which have less access to technological infrastructure, fewer schools and lower school enrolment than urban areas.

\section{Education system overview}

The 2004 Education Act and the 2010 National Education Policy (which is currently under review) are the organising documents for the education sector. ${ }^{3}$ The current Education Sector Plan sets out four levels of formal education provision:

- Pre-primary education, consisting of three years of pre-school education.

- Primary education, lasting six years.

- Secondary education, which is divided into three years of compulsory junior secondary education, and for those who pass the Basic Education Certificate Examination, three years of upper secondary education. Upper secondary education

\footnotetext{
${ }^{2}$ Ministry of Basic and Senior Secondary Education (2020), available at https://planipolis.iiep.unesco.org/en/2020/covid-19-education-emergency-response-plan-6954 ${ }^{3}$ Ministry of Education, Youth and Sports (2010), available at https://mbsse.gov.sl/wp-content/uploads/2020/03/2010-National-Education-Policy.pdf
} 
is either general education or TVET (technical and vocational education and training).

- Tertiary education, including teacher education and courses offered by universities, polytechnics and professional colleges, generally taking two to four years.

Participation in early childhood education and basic education is compulsory. The Constitution of Sierra Leone provides for "free compulsory basic education at primary and junior secondary school levels" and "free senior secondary education as and when practicable" (Government of Sierra Leone, 1991: 9). In August 2018, the government launched 'Free Quality School Education', a five-year initiative that sets out to make pre-primary, primary and secondary education free of charge for all pupils studying at government-approved schools (Maada Bio, 2018).

More than half of schools are operated outside of government control, with operators including religious organisations, local communities or private companies. Government schools constitute only $18 \%$ of primary schools and $10 \%$ of secondary schools (World Bank, 2019). Many non-government schools are nevertheless designated as 'approved schools', with a corresponding entitlement to financial support from the government. In recent years, the government has looked to regularise unapproved schools, approving those able to meet minimum standards, while aiming to close the remainder once nearby alternative provision is available (Ministry of Education, Science and Technology, 2018). As of 2019, according to the Annual School Census, $79 \%$ of primary schools, $77 \%$ of junior secondary schools and $80 \%$ of senior secondary schools are now approved.

Overall responsibility for the education system is shared between the Ministry of Basic and Senior Secondary Education (MBSSE) and the Ministry of Technical and Higher Education. Significant agencies reporting to the MBSSE, include the Teaching Services Commission, which is tasked with improving teacher management and performance.

Sierra Leone also has a separate Ministry of Social Welfare, Gender and Children's Affairs, which works closely with the education ministries. This is a cross-cutting ministry, focused on marginalised groups such as women, people with disabilities and the elderly.

The government has substantially increased expenditure as a proportion of GDP, from $2.59 \%$ of GDP (and 12.8\% of total government expenditure) in 2011 to $7.14 \%$ of GDP (and $32.47 \%$ of government expenditure) in 2018 (UNESCO, 2020). Going forward, the government has pledged to spend $21 \%$ of its recurrent budget on education.

\subsection{Education sector progress and challenges}

Despite high enrolment rates, the education system in Sierra Leone suffers from high levels of learner drop-out (particularly for girls) and grade repetition. Learning outcomes also require improvement.

Sierra Leone has seen a consistent increase in overall school enrolment rates, with primary net enrolment of $98 \%$ in 2016 and gross enrolment consistently in excess of 110\%, reflecting high levels of grade repetition. At secondary level, enrolment rates are 
substantially lower however, with gross enrolment at 41.8\% in 2017 (38.3\% net) (UNESCO, 2020). Girls are under-represented in senior secondary schools, with a Gender Parity Index (GPI) of 0.9 , though steady progress is being made towards closing this gap. Overall enrolment rates for children with disabilities are thought to be less than $50 \%$ (Ministry of Education, Science and Technology, 2018: 14-20).

Barriers to increasing enrolment include the affordability of schooling for learners, lack of schools within a reasonable distance, overcrowding of existing school buildings and lack of adequate WASH facilities in schools. At secondary level, female retention is also affected by sexual harassment and early pregnancy and marriage. (Ibid.).

Learning outcomes are low, both in absolute terms and in comparison to other countries in the region, with the average student completing the equivalent of just 4.5 learning-adjusted school years (World Bank, 2019). At secondary level, less than $20 \%$ of pupils entered for the West African Senior School Certificate Examination receive a passing mark (Ministry of Economic Development and Planning, 2019: 42). Barriers to improving learning outcomes include insufficient textbooks and learning materials, low levels of qualifications and motivation among the teaching workforce, and a large number of unapproved schools operating outside of the purview of the Ministry. Additional challenges identified in the most recent World Bank (2019) analysis include limitations in the primary and junior secondary curriculum and limitations in management and governance capacity.

\subsection{Education Sector Plan 2018-2020}

Sierra Leone's third Education Sector Plan 2018-2020 (ESP) provides a transitional framework for the improvement of the country's education system (Ministry of Education, Science and Technology, 2018). The ESP identifies three intended outcomes:

1. Improved levels of service delivery

2. Improved learning outcomes

3. Improved system integrity, (i.e., a reduction in the incidence of corrupt practices by administrators, teachers and other key actors).

The objectives set out in the ESP are:

1. Improved access, equity and completion rates in the education system

2. Improved quality and relevance of the education system and its constituent programmes to attain the highest possible level of integrity and performance

3. Strengthened education system

4. Increased emergency preparedness to enable a better response to external shocks.

\subsection{Medium-Term Development Plan 2019-2023}

Since the production of the 2018-2020 ESP, there has been a change of government in Sierra Leone. The new government's vision for basic and secondary education is set out in 
the Medium-Term Development Plan (Ministry of Economic Development and Planning, 2019: 36-45), which sets out four key targets for the sector to achieve by 2023:

1. Implement free, quality basic and secondary-school education.

2. Increase access, equity and completion rates at all levels of schooling (formal and non-formal) above the 2018 rates.

3. Improve the basic and senior secondary learning environment at all levels above the 2018 rates.

4. Review and strengthen educational systems and governance architecture for improved quality education.

In August 2018, the government launched its flagship policy, 'Free Quality School

Education', a five-year initiative with a headline commitment to make pre-primary, primary and secondary education free of charge for all pupils (Maada Bio, 2018). The policy will also see the provision of stationery, equipment and core subject textbooks to government-supported schools, though parents and guardians are expected to cover the costs of school uniforms and the cost of repeating more than one year in each stage of schooling.

\section{EdTech policy and strategy}

In this section, we describe Sierra Leone's national ICT policy and include a brief look at the ICT in education policy.

\subsection{National policy}

An ambitious National Innovation and Digital Strategy (2019-29) was published in 2019 (Directorate of Science, Technology \& Innovation, 2019a). The strategy identifies 'mobile-first' as a key principle for the development of digital services, recognising that levels of mobile phone penetration are far higher than other communication technologies. It identifies that action is required to increase mobile phone penetration rates and reduce the cost of access.

Six short-term strategic areas are identified, many of which have some relevance to EdTech:

1. 'National Digital Identities' - an aspiration to issue and maintain digital identities for $90 \%$ of citizens. This strand will likely have implications for how data on learner and system outcomes is collected and used.

2. 'Applied Al for Governance' — which would see Sierra Leone providing a platform for Al / data science research to improve public services. One of the use cases listed in this strand is education: "use of Al to understand the effect of school, student and teacher attributes on learning outcomes to inform prioritisation of education interventions at all levels".

3. 'Infrastructure' - including activity to improve access to connectivity. 
4. 'Security' - including cybersecurity, quantum computing and development of regionally appropriate IT standards.

5. 'Entrepreneurship and Society' - including support for incubators and accelerators, $R \& D$, and efforts to create a culture shift. For schools, it is anticipated that this may involve changes to the curriculum to include more focus on "hands-on learning, computation and coding, comprehension and communication, and critical thinking". This area will also see the Education Ministries collaborate to develop a policy on Fourth Industrial Revolution technologies.

6. 'Organisational Architecture' - including the establishment of an Information System Authority to guide and regulate the government's digital transformation and establishment of a data protection body.

\subsection{ICT in education policy}

Sierra Leone currently does not have an ICT in Education policy, however, there are plans to introduce one. ICT in Education, is however, explicitly, albeit briefly, mentioned in the latest Education Sector Plan, with an emphasis on the use of technology to augment, rather than replace, current teaching and bridging the gap between well-provisioned and less-well-provisioned schools (Ministry of Education, Science and Technology, 2018: 56).

\section{ICT infrastructure}

At the national level, household ownership of mobile phones is moderately high (71\%), though this varies significantly by location, with a forty percentage point gap in mobile phone ownership in urban and rural areas. 'Feature' phones are more prevalent than smartphones. Ninety per cent of the population live in areas with high-performance $2 \mathrm{G}$ mobile connectivity, though $3 G$ (43\%) and 4G (46\%) coverage is more limited (GSMA, 2018). Sierra Leone was an early adopter of mobile money services, with the government actively encouraging their ongoing development.

Across all contexts, few households have access to computers, just 5.7\% overall, with less than 1\% ownership in rural areas. Households also have limited access to the internet (14\%), though this again varies significantly between urban and rural areas (Table 1).

At the school level, upper secondary schools are much better equipped with ICT infrastructure than primary schools, though overall levels of coverage are low. Upper secondary schools are nearly 14 times more likely to have access to the internet for teaching and learning, compared to primary schools, and 6 times more likely to have access to electricity (Table 3). The 2019 Annual Schools Census indicates that $86 \%$ of schools are in areas with mobile phone network coverage.

The Medium-Term Development Plan sets out targets for the further development of digital infrastructure, including for $30 \%$ of the population to have access to broadband services by 2023 and for $80 \%$ to have access to mobile services. 
Table 2. Percentage of households who own a radio, television, fixed telephone line, mobile phone, and computer, and that have access to the internet at home. ${ }^{4}$

\begin{tabular}{|l|r|}
\hline $\begin{array}{l}\text { Information and Communication } \\
\text { Technology }\end{array}$ & Percentage \\
\hline Radio & 54.7 \\
\hline Television & 18.2 \\
\hline Telephone - fixed line & 0.7 \\
\hline Telephone - mobile & 71.4 \\
\hline Computer & 5.7 \\
\hline Access to the internet at home & 13.8 \\
\hline
\end{tabular}

Table 3. Percentage of urban and rural households with radio, mobile phone, computer or internet at home. ${ }^{5}$

\begin{tabular}{|l|r|r|}
\hline & Urban & Rural \\
\hline Radio & 66.9 & 44.8 \\
\hline Mobile & 93.5 & 53.4 \\
\hline Computer & 11.6 & 0.8 \\
\hline Internet & 26.3 & 3.7 \\
\hline
\end{tabular}

Table 4. EdTech infrastructure in schools. ${ }^{6}$

\begin{tabular}{|l|r|}
\hline Infrastructure & Percentage with access \\
\hline Electricity & 5.6 \\
\hline Primary school & 17.5 \\
\hline Junior high school & 33.7 \\
\hline Senior high school & \\
\hline Internet for teaching and learning & \\
\hline
\end{tabular}

${ }^{4}$ UNICEF (2017), available at https://www.statistics.sl/images/StatisticsSL/Documents/sierra leone mics6 2017 report.pdf ${ }^{5}$ Ibid.

${ }^{6}$ UNESCO (2018), available at http://data.uis.unesco.org/index.aspx?queryid=3483 


\begin{tabular}{|l|r|}
\hline Primary school & 0.6 \\
\hline Junior high school & 3.0 \\
\hline Senior high school & 7.8 \\
\hline Computers for teaching and learning & \\
\hline Primary school & 2.6 \\
\hline Junior high school & 12.9 \\
\hline Senior high school & 21.9 \\
\hline
\end{tabular}

\section{Key partners and initiatives in EdTech}

This section looks at the work and roles and responsibilities of key partners with regard to EdTech in Sierra Leone, including government and non-governmental agencies, as well as EdTech initiatives.

\subsection{Government agencies}

The Directorate of Science, Technology and Innovation (DSTI) has been established as an innovation function within the Office of the President. Several of its projects are education focussed. Dr David Sengah, who as Chief Innovation Officer heads DSTI, was promoted to serve concurrently as Minister for Basic and Senior Secondary in 2019.

Many of the projects which have been pursued by DSTI and MBSSE are designed to improve the data available to decision-makers and move the Ministry towards having a "fully integrated education analytics platform" (O'Connor \& Zurutuza, 2019). DSTI projects to date have included:

- development of an Education Data Hub, bringing together previously disparate datasets to inform decision-making and problem solving (Directorate of Science, Technology \& Innovation, 2019);

- development of a School Optimisation Tool, which maps data on school locations and bus stops (Directorate of Science, Technology \& Innovation, 2020);

- development of a new portal to streamline and digitise teacher recruitment and allocation (Directorate of Science, Technology \& Innovation, 2019);

- development of the Sierra Leone Education Innovation Challenge (featured in Table 6 below).

Previous collaboration between UNICEF and the Education Ministry supported the piloting and development of the government's Education Management Information Systems (EMIS) (Ministry of Basic and Senior Secondary Education, 2020). More recent funding from the Global Partnership for Education has supported the integration of EMIS with 'The Situation Room', a unit within the Ministry that tracks performance in a representative sample of 
schools (Ministry of Education, Science and Technology, 2018). The World Bank has also previously supported the development of data capability through a US\$1 m strand of the Revitalizing Education Development in Sierra Leone (REDiSL) programme (World Bank, 2014). In 2018, the Ministry of Finance, World Bank and DFID also collaborated on transitioning the school census to digital data collection using tablets (Namit \& Mai, 2019). Table 5 describes the roles of additional government partners in EdTech.

Table 5. Key government partners in EdTech

\begin{tabular}{|c|c|}
\hline Ministry / Agency & Roles and responsibilities in EdTech \\
\hline $\begin{array}{l}\text { Directorate of Science, } \\
\text { Technology and Innovation }{ }^{7}\end{array}$ & $\begin{array}{l}\text { - Using science, technology and innovation to support } \\
\text { the Government of Sierra Leone to deliver on the } \\
\text { national development plan. } \\
\text { - Supporting decision-making through analysis and } \\
\text { visualisation. }\end{array}$ \\
\hline $\begin{array}{l}\text { Ministry of Information and } \\
\text { Communications }^{8}\end{array}$ & $\begin{array}{l}\text { - Facilitating universal, ubiquitous and cost-effective } \\
\text { access to information and communications } \\
\text { infrastructure and services throughout the country. } \\
\text { - Promoting the utilisation of ICT in all spheres of life. } \\
\text { - Formulating and implementing information and } \\
\text { communications technology policy. }\end{array}$ \\
\hline $\begin{array}{l}\text { Teacher Services } \\
\text { Commission }\end{array}$ & $\begin{array}{l}\text { - Licensing, recruitment, posting, induction and } \\
\text { development of teachers in government and } \\
\text { government-supported schools. } \\
\text { - A key partner in the development of a digital teacher } \\
\text { recruitment platform (see above) and future World } \\
\text { Bank-funded technology-enabled teacher CPD } \\
\text { programme (see Table } 6 \text { below). }\end{array}$ \\
\hline $\begin{array}{l}\text { Universal Access } \\
\text { Development Fund (UADF) }\end{array}$ & $\begin{array}{l}\text { - Promoting universal access to IT and broadband } \\
\text { services, including through developing the fibre, mobile } \\
\text { phone and broadband networks. } \\
\text { Running Schools ICT Centres programme, which } \\
\text { installs computer labs in secondary schools and an } \\
\text { e-libraries programme, providing infrastructure and } \\
\text { capacity building (Universal Access Development Fund, } \\
\text { 2020). }\end{array}$ \\
\hline $\begin{array}{l}\text { Sierra Leone Cable Ltd } \\
\text { (SALCAB) }^{10}\end{array}$ & $\begin{array}{l}\text { - Government-owned infrastructure company, with a } \\
\text { mandate to improve digital connectivity, starting with } \\
\text { schools and health facilities. }\end{array}$ \\
\hline
\end{tabular}

${ }^{7}$ DSTI | Home (2020), available at https://www.dsti.gov.sl/

8 Ministry of Information and Communications | Home (2020), available at https://mic.gov.sl/

${ }^{9}$ Universal Access Development Fund | Home (2020), available at https://uadf.gov.sl/

${ }^{10}$ SALCAB | Home (2020), available at https://www.salcab.sl/ 


\subsection{Non-governmental agencies}

The Education Ministry has implemented several initiatives with digital components with the support of development partners, particularly the World Bank, DFID and UNICEF. Smaller-scale and pilot projects have also been implemented by NGOs including World Reader, Commonwealth of Learning and CAUSE Canada. Table 6 lists key funding and implementing partners alongside the initiatives they are supporting.

\subsection{EdTech initiatives}

EdTech initiatives have been in three main areas. Firstly, as noted in 6.1 above, there has been sustained investment in activities to improve the data available to the Ministry to inform educational interventions. Secondly, a number of initiatives have been focused on the use of technology to deliver teacher education.

Table 6. Recent EdTech initiatives in Sierra Leone.

\begin{tabular}{|c|c|}
\hline Initiative & Details \\
\hline \multirow[t]{7}{*}{$\begin{array}{l}\text { Sierra Leone Education } \\
\text { Innovation Challenge }{ }^{11}\end{array}$} & $\begin{array}{l}\text { Overview: Programme will set target literacy and numeracy } \\
\text { learning outcomes in schools needing additional support. } \\
\text { Innovative interventions will be implemented by non-state } \\
\text { providers using an outcomes-based payment model (with up to } \\
\text { US } \$ 20 \mathrm{~m} \text { available from government and donors). }\end{array}$ \\
\hline & $\begin{array}{l}\text { Target group: Learners in primary schools, particularly in rural } \\
\text { areas. }\end{array}$ \\
\hline & $\begin{array}{l}\text { Technology: Not yet finalised, but Phase II of the programme } \\
\text { likely to include radio, TV, SMS, low-data mobile delivery and } \\
\text { potentially tablet access. Phase II has been focused on distance } \\
\text { learning and EdTech in light of the Covid-19 pandemic. }\end{array}$ \\
\hline & $\begin{array}{l}\text { Reach / scale: } 500 \text { schools, } 250,000 \text { pupils in Phase II, } \\
\text { country-wide in Phase III. }\end{array}$ \\
\hline & $\begin{array}{l}\text { Implementing organisations: Education Outcomes Fund, Tony } \\
\text { Blair Institute for Global Change. Phase I partners are Save the } \\
\text { Children, Rising Academy Network, EducAid, National Youth } \\
\text { Awareness Forum, Sierra Leone and World Vision. }\end{array}$ \\
\hline & $\begin{array}{l}\text { Government partners: Ministry of Basic and Senior Secondary } \\
\text { Education; Directorate of Science, Technology and Innovation. }\end{array}$ \\
\hline & $\begin{array}{l}\text { Status of implementation: Phase I Pilot running in } 2019 \text { / } 20 . \\
\text { Phase II scale-up from September 2020. Phase III National }\end{array}$ \\
\hline
\end{tabular}

${ }^{11}$ Sierra Leone Education Innovation Challenge (2019), available at https://www.dsti.gov.sl/sierra-leone-invests-1-5-million-to-bring-education-innovation-to-schools-forbetter-learning-outcomes/ 


\begin{tabular}{|c|c|}
\hline & scale-up from 2023. \\
\hline $\begin{array}{l}\text { Sierra Leone Free } \\
\text { Education Project }^{12}\end{array}$ & $\begin{array}{l}\text { Overview: A major strand of this US } \$ 86 m \text { World Bank-led } \\
\text { programme is a US } \$ 19 \text { m investment in developing and delivering } \\
\text { a scalable technology-enabled, continuous, in-service teacher } \\
\text { training programme. } \\
\text { Also includes data capacity-building support for the Ministry and } \\
\text { support for the use of tablets to conduct an Annual School } \\
\text { Census. } \\
\text { Target group: Primary school teachers. } \\
\text { Technology: Solar-powered tablets. } \\
\text { Reach / scale: Country-wide. } \\
\text { Implementing organisations: World Bank. Co-financing from } \\
\text { DFID, Irish Aid and EU. } \\
\text { Government partners: Teacher Services Commission, Ministry } \\
\text { of Basic and Secondary Education. } \\
\text { Status of implementation: Pipeline. } 2019-24 \text {. }\end{array}$ \\
\hline Rising On Air ${ }^{13}$ & $\begin{array}{l}\text { Overview: Radio programme that provides lessons scripts and } \\
\text { re-recorded audio content designed specifically for radio. Radio } \\
\text { content is supplemented by complementary SMS content aimed } \\
\text { at parents, and phone calls aimed at parents and students } \\
\text { (Lamba and Reimers, 2020). } \\
\text { Target group: Parents and students ( } 5 \text { levels from early } \\
\text { childhood education through to senior secondary school) } \\
\text { Technology: Radio, SMS, audio files, phone calls } \\
\text { Reach / scale: International - with an aspiration to reach } 10 \\
\text { million learners. Materials are uploaded online and free to re-use } \\
\text { and adapt. } \\
\text { Implementing partners: Rising Academies, local radio stations. } \\
\text { Government partners: Ministry of Basic and Secondary } \\
\text { Education. } \\
\text { Status: } 2020 \text { - }\end{array}$ \\
\hline
\end{tabular}

\footnotetext{
${ }^{12}$ World Bank (2019), available at http://documents1.worldbank.org/curated/en/711051560267527870/pdf/Project-Information-Docu ment-Sierra-Leone-Free-Education-Project-P167897.pdf

${ }_{13}$ Rising Academies (2020), available at https://www.risingacademies.com/onair
} 


\begin{tabular}{|c|c|}
\hline World Reader ${ }^{14}$ & $\begin{array}{l}\text { Overview: Three small-scale projects making e-Readers loaded } \\
\text { with content available to primary school pupils, community } \\
\text { members. } \\
\text { Target group: Primary school pupils. } \\
\text { Technology: eReaders. } \\
\text { Reach / scale: c. } 700 \text { pupils across } 3 \text { projects. A further 3,500 } \\
\text { Sierra Leoneans access World Reader content via mobile } \\
\text { phones. } \\
\text { Implementing organisations: World Reader, Street Child. } \\
\text { Government partners: n/a } \\
\text { Status of implementation: } 2015-P r e s e n t .\end{array}$ \\
\hline $\begin{array}{l}\text { Integrated In-Service } \\
\text { Teacher Training Project } \\
\text { for Junior Secondary } \\
\text { School Teachers }{ }^{15}\end{array}$ & $\begin{array}{l}\text { Overview: Aims to improve teacher quality through "scalable } \\
\text { technology-enabled, school-based teacher development". } \\
\text { Activity in Sierra Leone has principally involved capacity-building } \\
\text { and resource development. This has included training } \\
\text { workshops, creation of a community of practice for participants } \\
\text { and development / contextualisation of a toolkit and } \\
\text { implementation guide. } \\
\text { Target group: Teachers in junior secondary schools. } \\
\text { Technology: Open Educational Resources (OERs). } \\
\text { Reach / scale: } 12 \text { schools. } \\
\text { Implementing organisations: Commonwealth of Learning, } \\
\text { Freetown Teachers College. } \\
\text { Government partners: Former Ministry of Education, Science } \\
\text { and Technology. } \\
\text { Status of implementation: } 2018-P r e s e n t .\end{array}$ \\
\hline
\end{tabular}

\footnotetext{
${ }^{14}$ Worldreader | Sierra Leone (2020), available at https://www.worldreader.org/where-we-are/sierra-leone/

${ }^{15}$ Commonwealth of Learning (2020), available at http://oasis.col.org/bitstreaDigital Reading in Sierra Leone

Schoolsm/handle/11599/3546/2018-2020 Africa Sierra Leone Country Highlights.pdf?sequence=1\& isAllowed=y
} 


\begin{tabular}{|c|c|}
\hline Mobile Learning Lab ${ }^{16}$ & $\begin{array}{l}\text { Overview: Makes learning resources / content available to } \\
\text { off-grid communities without electricity and internet. } \\
\text { Target group: Grade 4, } 5 \text { and } 6 \text { students in rural northern Sierra } \\
\text { Leone (Koinadugu district). } \\
\text { Technology: Tablets, solar charging system, RACHEL-Plus } \\
\text { rechargeable server, OERs. } \\
\text { Reach / scale: Five communities, } 750+\text { pupils (pilot project). } \\
\text { Implementing organisations: } 60 \text { million girls Foundation, } \\
\text { CAUSE Canada. } \\
\text { Government partners: None. } \\
\text { Status of implementation: } 2013-2018\end{array}$ \\
\hline $\begin{array}{l}\text { Leh Wi Learn - Sierra } \\
\text { Leone Secondary } \\
\text { Education Improvement } \\
\text { Programme }\end{array}$ & $\begin{array}{l}\text { Overview: } £ 62.5 m \text { DFID-funded programme focused on } \\
\text { improving attendance and learning outcomes for girls and } \\
\text { children with disabilities in government secondary schools. The } \\
\text { programme has seen new lesson plans and textbooks designed } \\
\text { and widely disseminated (Ministry of Basic and Senior Secondary } \\
\text { Education, 2020). } \\
\text { Target group: Girls and children with disabilities in secondary } \\
\text { schools. } \\
\text { Technology: Tablets (as a management tool), Radio. } \\
\text { The open-source Tangerine platform has been used to collect } \\
\text { data on school performance, as an input into planning and policy } \\
\text { development. } \\
\text { Another component of the programme has seen the distribution } \\
\text { of 2,640 wind-up radios pre-loaded with lessons on gender, } \\
\text { adolescence, sexual and reproductive health and reporting } \\
\text { violence in schools. } \\
\text { Reach / scale: Country-wide. } \\
\text { Implementing organisations: UK Department for International } \\
\text { Development, UNICEF, Cambridge Education, PwC, International } \\
\text { Rescue Committee, World Vision. } \\
\text { Government partners: Ministry of Basic and Senior Secondary } \\
\text { Education. } \\
\text { Status of implementation: } 2016-2021 \text {. }\end{array}$ \\
\hline
\end{tabular}

${ }^{16} 60$ Million Girls (2018), available at https://60millionsdefilles.org/en/rd/evaluation-report/

${ }^{17}$ Ministry of Basic and Senior Secondary Education (2020), available at http://www.education.gov.sl/LeWeLearn Page/LeWeLearn index.aspx 
In response to the Ebola epidemic in 2014-2016, Sierra Leone developed and deployed a system of radio education to keep pupils learning while schools were closed. Similar efforts have been deployed in response to Covid-19-related school closures.

\section{Box 1. Radio Education during the Ebola Crisis}

The West Africa Ebola epidemic of 2014-16 saw the closure of all of Sierra Leone's schools for a full academic year. The government commissioned an Emergency Radio Education Programme - broadcasting half-hour programmes each weekday in maths, English and civics. To improve the reach of the programme, UNICEF distributed 25,000 radios to poorer communities, though in some rural areas access was limited due to lack of radio signal.

Radio education was adopted by other organisations delivering education programmes in Sierra Leone. The 'Getting Ready for School Project', funded by Comic Relief, developed trilingual radio programmes, aimed at three age groups and covering self-esteem, literacy, numeracy, health education and PSHE. Uptake was encouraged through the distribution of wind-up radios and training facilitators to host listening groups (Barnett et al., 2018).

Similar efforts have been deployed in response to Covid-19-related school closures.

\section{Box 2. The Government of Sierra Leone education sector response to Covid-19}

On March 19, before the first case of Covid-19 in Sierra Leone, the Government announced that all schools should close by March 31.

A Covid-19 education response plan setting out the actions to be taken by Government and Education Development Partners was published in May 2020 (Ministry of Basic and Senior Secondary Education, 2020). The plan has four pillars:

1. Communications and Social Mobilisation (including awareness-raising)

2. Continuous Distance Learning

3. School Reopening Readiness

4. Operations, Planning and Policy

Drawing on experience from the Ebola pandemic, the week after schools closed, an emergency radio education programme was launched, broadcasting five 30-minute episodes per week covering core academic subjects. The government is planning to increase the reach of these broadcasts to the substantial minority of households without a radio by installing radio transmitters in rural areas without coverage and distributing solar-powered radios. There are plans to supplement the radio broadcasts with mobile apps, printed packets of materials for pupils with no access to technology, and TV, SMS, USSD and web-based activities. 
Alongside this, teacher training covering digital literacy, digital lesson delivery and accelerated learning will take place through WhatsApp, SMS, TV, radio and online platforms to help the workforce to adapt (ibid).

The Ministry of Basic and Senior Secondary Education has developed an e-learning platform on the Ministry website - containing downloadable maths and English lesson plans and pupil handbooks for primary and secondary education, lesson plans for pre-primary education, and links to other online learning resources.

The mobile network operator Orange has partnered with MBSSE to allow citizens to access a range of educational sites on their network without charge (Orange, 2020).

\section{Looking Ahead}

There is a high level of political commitment, from the President down, to improving the education system and harnessing the potential of digital technology. Within the National Development Plan, the Government has recognised the value that digital can add to efforts to stimulate economic growth, while the launch of the flagship Free Quality School Education Initiative was one of the first acts of the current government.

Existing large-scale EdTech initiatives appear to be well-integrated within wider, system-reform programmes. There are, however, significant constraints to successful use of EdTech in Sierra Leone - principally, poor infrastructure (with low levels of technological penetration), and the limited experience of the teaching workforce in using technology in teaching and learning.

Current, ongoing work to develop a new Education Sector Plan for 2021-2025 and refresh the 2010 Education Policy (as well as the mooted development of an ICT in Education Policy) provide important opportunities to set a framework for the effective use of EdTech to improve learning outcomes and system capacity in Sierra Leone. 


\section{Further reading}

Kaye, T., Groeneveld, C., Moss, C., \& Haßler, B. (2020). Nepal "Ask me anything" Session: Responses to audience questions (EdTech Hub Helpdesk Response No. 13). EdTech Hub.

Moss, C. (2020a, January 22). 18 large-scale EdTech initiatives on our radar in 2020. The EdTech Hub.

Moss, C. (2020b, January 24). 15 EdTech research papers that we share all the time. The EdTech Hub.

Trucano, M. (2013). 10 principles to consider when introducing ICTs into remote, low-income educational environments.

https://blogs.worldbank.org/edutech/10-principles-consider-when-introducing-icts-re mote-low-income-educational-environments 


\section{References}

60 Million Girls. (2018). Mobile Learning Lab Evaluation \& Analysis. 60 Million Girls. https://60millionsdefilles.org/en/rd/evaluation-report/

Barnett, S., van Dijk, J., Swaray, A., Amara, T., \& Young, P. (2018). Redesigning an education project for child friendly radio: A multisectoral collaboration to promote children's health, education, and human rights after a humanitarian crisis in Sierra Leone. BMJ, 363.

Commonwealth of Learning. (2020). COL in the Commonwealth: Sierra Leone. http://oasis.col.org/bitstream/handle/11599/3546/2018-2020 Africa Sierra Leone Country Highlights.pdf?sequence $=1$ \&isAllowed $=y$

Directorate of Science, Technology \& Innovation (Sierra Leone). (2019a). Sierra Leone National Innovation and Digital Strategy. https://www.dsti.gov.sl/wp-content/uploads/2019/11/Sierra-Leone-National-Innov ation-and-Digital-Strategy.pdf

Directorate of Science, Technology \& Innovation (Sierra Leone). (2019b, September 16). Sierra Leone turns to technology and analytics to put quality back into education. https://www.dsti.gov.sl/sierra-leone-turns-to-technology-and-analytics-to-put-qual ity-back-into-education/

Directorate of Science, Technology \& Innovation (Sierra Leone). (2019c, December 23). Sierra Leone designs online portal to take long wait out of teacher recruitment. https://www.dsti.gov.sl/sierra-leone-designs-online-portal-to-take-long-wait-out-of -teacher-recruitment/

Directorate of Science, Technology \& Innovation (Sierra Leone). (2020a). DSTI | Home. https://www.dsti.gov.sl/

Directorate of Science, Technology \& Innovation (Sierra Leone). (2020b, January 22). Scientists at DSTI go the extra mile to make it easier for children to get to school. https://www.dsti.gov.sl/scientists-at-dsti-go-the-extra-mile-to-make-it-easier-for-ch ildren-to-get-to-school/

Government of Sierra Leone. (1991). Constitution of Sierra Leone.

GSMA. (2018). GSMA Mobile Connectivity Index | Sierra Leone. https://www.mobileconnectivityindex.com/ 
Kaye, T., Groeneveld, C., Moss, C., \& Haßler, B. (2020). Nepal "Ask me anything" Session: Responses to audience questions (EdTech Hub Helpdesk Response No. 13). EdTech Hub.

Lamba, K., \& Reimers, F. (2020). Sierra Leone and Liberia: Rising Academy Network on air. https://oecdedutoday.com/wp-content/uploads/2020/05/Sierra-Leone-Liberia-Risi ng-Academy-Network.pdf

Maada Bio, J. (2018). Education for Development.

https://www.sierra.amavserver.com/wp-content/uploads/2018/12/Statement-byHE.-President-Julius-Maada-Bio-on-the-Launching-of-the-Free-Education-20.08.20 18.pdf

Ministry of Basic and Senior Secondary Education (Sierra Leone). (2020a). COVID-19 Education Emergency Response Plan. https://planipolis.iiep.unesco.org/sites/planipolis/files/ressources/sierra-leone-cov id19-education-response-plan-pdf.pdf

Ministry of Basic and Senior Secondary Education (Sierra Leone). (2020b). EMIS | Education Management Information System. https://mbsse.gov.s//emis/

Ministry of Basic and Senior Secondary Education (Sierra Leone). (2020c). Leh Wi Lan: Improving The Quality Of Secondary Education In Sierra Leone. http://www.education.gov.sl/LeWeLearn Page/LeWeLearn index.aspx

Ministry of Education, Science and Technology (Sierra Leone). (2018a). Education Sector Plan 2018-2020.

https://planipolis.iiep.unesco.org/sites/planipolis/files/ressources/sierra leone ed ucation sector plan 2018-2020 0.pdf

Ministry of Education, Science and Technology (Sierra Leone). (2018b). Proposal to the Global Partnership for Education for a contribution towards the implementation of the 2018-2020 Education Sector Plan. https://www.globalpartnership.org/sites/default/files/2018-10-sierra-leone-progra m-document-2018-2020.pdf

Ministry of Education, Youth and Sports (Sierra Leone). (2010). National Education Policy. https://mbsse.gov.sl/wp-content/uploads/2020/03/2010-National-Education-Policy .pdf

Ministry of Information and Communications (Sierra Leone). (2020). Ministry of Information and Communications | Home. https://mic.gov.sl/ 
Ministry of Planning and Economic Development (Sierra Leone). (2019). Sierra Leone Medium Term National Development Plan (Volume 1). http://www.moped.gov.sl/wp-content/uploads/2019/03/Medium-Term-National-D evelopment-Plan-Volume-I.pdf

Moss, C. (2020a, January 22). 18 large-scale EdTech initiatives on our radar in 2020. The EdTech Hub. https://edtechhub.org/2020/01/22/18-large-scale-edtech-initiatives-on-our-radar-i $\underline{\mathrm{n}-2020 /}$

Moss, C. (2020b, January 24). 15 EdTech research papers that we share all the time. The EdTech Hub.

Namit, K., \& Mai, T. T. (2019). Digital School Census in 10 Weeks? How it was done in Sierra Leone. World Bank Blogs. https://blogs.worldbank.org/education/digital-school-census-10-weeks-how-it-was -done-sierra-leone

O'Connor, S., \& Zurutuza, N. (2019). Sierra Leone: Transforming the Country through Innovation. UNICEF. https://www.unicef.org/innovation/stories/sierra-leone-transforming-country-thro ugh-innovation

Orange Sierra Leone. (2020). Orange Education Portal. /personal/1/101/orange-education-2986.html

Rising Academies. (2020). Rising On Air. https://www.risingacademies.com/onair

SALCAB. (2020). SALCAB | Home. https://www.salcab.sl/

Sierra Leone Education Innovation Challenge. (2019). Sierra Leone invests $\$ 1.5$ million to bring education innovation to schools for better learning outcomes. https://www.dsti.gov.sl/sierra-leone-invests-1-5-million-to-bring-education-innovat ion-to-schools-for-better-learning-outcomes/

Trucano, M. (2013). 10 principles to consider when introducing ICTs into remote, low-income educational environments. https://blogs.worldbank.org/edutech/10-principles-consider-when-introducing-ict s-remote-low-income-educational-environments

UNESCO. (2018). Proportion of schools with access to basic facilities, all schools. http://data.uis.unesco.org/index.aspx?queryid=3483 
UNESCO. (2020). Sierra Leone | Education and Literacy Statistics.

http://uis.unesco.org/en/country/sl

UNICEF. (2017). Sierra Leone Multiple Indicator Cluster Survey.

https://www.statistics.sl/images/StatisticsSL/Documents/sierra leone mics6 2017 report.pdf

Universal Access Development Fund (Sierra Leone). (2020a). Schools ICT project. https://uadf.gov.sl/schools-ict-project/

Universal Access Development Fund (Sierra Leone). (2020b). Universal Access Development Fund | Home. https://uadf.gov.sl/

World Bank. (2014). Revitalizing Education Development in Sierra Leone (REDISL) Project. http://documents1.worldbank.org/curated/en/909691468299196446/pdf/879000 PAD0P1330018034002000with0MAP.pdf

World Bank. (2019). Project Information Document: Sierra Leone Free Education Project. http://documents1.worldbank.org/curated/en/711051560267527870/pdf/Project-I nformation-Document-Sierra-Leone-Free-Education-Project-P167897.pdf

Worldreader. (2020). Worldreader | Sierra Leone. https://www.worldreader.org/where-we-are/sierra-leone/ 